\title{
Cultural diversity and entrepreneurship: a regional analysis for Germany
}

\author{
David Audretsch • Dirk Dohse • \\ Annekatrin Niebuhr
}

Received: 15 October 2007 / Accepted: 17 July 2008 / Published online: 13 March 2009

(C) The Author(s) 2009. This article is published with open access at Springerlink.com

\begin{abstract}
In this paper, we investigate the determinants of entrepreneurial activity in a cross section of German regions for the period 1998-2005. Departing from the knowledge spillover theory of entrepreneurship, the focus of our analysis is on the role of the regional environment and, in particular, knowledge and cultural diversity. Our main hypothesis is that both, knowledge and diversity, have a positive impact on new firm formation. As the determinants of regional firm birth rates might differ considerably with respect to the necessary technology and knowledge input, we consider start-ups at different technology levels. The regression results indicate that regions with a high level of knowledge provide more opportunities for entrepreneurship than other regions. Moreover, while sectoral diversity tends to dampen new firm foundation, cultural diversity has a positive impact on technology oriented start-ups. This suggests that the diversity of people is more conducive to entrepreneurship than the diversity of firms. Thus, regions characterized by a high level of knowledge and cultural diversity form an ideal breeding ground for technology oriented start-ups.
\end{abstract}

JEL Classification $\mathrm{M} 13 \cdot \mathrm{O} 18 \cdot \mathrm{R} 11$

\section{Audretsch $(\bowtie)$}

Max Planck Instiute of Economics, Kahlaische Strasse 10, 07745 Jena, Germany

e-mail: audretsch@econ.mpg.de

\section{Dohse}

Kiel Institute for the World Economy, Düsternbrooker Weg 120, 24105 Kiel, Germany e-mail: dirk.dohse@ifw-kiel.de

\section{A. Niebuhr}

Institute for Employment Research (IAB Nord), Projensdorfer Straße 82, 24106 Kiel, Germany

e-mail: Annekatrin.Niebuhr@iab.de 


\section{Introduction}

The start-up and running of new business is central to modern economies' dynamics and their ability to innovate and grow. It is therefore not surprising that entrepreneurs, a species long-time neglected by mainstream economics, recently seem to regain the profession's attention. ${ }^{1}$ They are, however, no longer viewed as "lone giants" but rather as very interactive people who heavily depend on other people, resources and opportunities in their respective context.

If it is true that the spillover of new knowledge, which is arguably the most important input into the entrepreneurial process, is geographically localized (for empirical evidence see for instance Jaffe 1989; Audretsch and Feldmann 1996; Audretsch and Stephan 1996; Jaffe et al. 1993) then the regional context should be a particularly important determinant of entrepreneurship. Indeed, recent studies have shown the importance of regional factors such as agglomeration economies, regional R\&D or regional income growth in explaining differences in the entry rates of firms (Rosenthal and Strange 2003; Stuart and Sorenson 2003; Lee et al. 2004). The way in which regional diversity impacts entrepreneurial opportunity, which is the core issue of this paper, is, however, rarely explored.

We analyse the regional determinants of entrepreneurship as measured in terms of firm start-ups in Germany. The purpose of the analysis is threefold:

- The main focus of the paper is on investigating the role of the regional environment and, in particular, regional diversity with respect to new firm foundation. Our main hypothesis is that regional diversity-by which we mean the diversity of people (i.e. cultural diversity) and not necessarily the diversity of firms or industries within a region-fosters the recognition, absorption and realization of entrepreneurial opportunities and should therefore have a positive impact on new firm formation.

- Secondly, we ask whether regions with high levels of knowledge, measured by $\mathrm{R} \& \mathrm{D}$ and human capital, do indeed provide more entrepreneurial opportunities than other regions, as recent theoretical papers suggest.

- And thirdly we conjecture that the factors driving firm start-ups might differ considerably with respect to the technology (or knowledge) input necessary to start and run a certain business. We therefore consider different kinds of start-ups (i.e. total start-ups, technology oriented start-ups, start-ups in technology oriented services and high tech start-ups) and investigate whether the factors that influence the variation in regional firm birth rates differ systematically with respect to the technology level of the start-ups.

The paper is organised as follows. Section 2 provides the theoretical background on firm formation and regional diversity and specifies the econometric model in its basic form. Section 3 contains a detailed description of the data set and a discussion of the variables used in the estimations. Section 4 presents and discusses the results of the econometric analysis. Section 5 concludes.

\footnotetext{
1 See, for example, the influential contributions by Blanchflower and Oswald (1998), Lazear (2004) or Acemoglu et al. (2006).
} 


\section{Knowledge spillovers, cultural diversity, and entrepreneurship: theoretical background and econometric model}

\subsection{Theoretical background}

Economists have long observed that entrepreneurial activity tends to vary systematically across geographic space (Carlton 1983; Storey 1991; Reynolds et al. 1994). In searching for a theoretical framework to provide a lens through which spatial variation of entrepreneurship could best be interpreted and explained, scholars have gravitated towards models highlighting the extent to which entrepreneurial opportunities prevail or are impeded within a spatial context. This has generated an exhaustive literature linking region-specific characteristics that either promote or impede entrepreneurial opportunities to various measures of regional entrepreneurship. Most notably, region-specific measures, such as growth, unemployment, population density, taxes, and industry structure have been found to influence the extent of entrepreneurial activity within a region. Steil (1999) presents a comprehensive survey of the literature before 1999. Empirical studies for Germany are provided by Audretsch and Fritsch (1994, 2002), Fritsch and Falck (2007) as well as by Rocha and Sternberg (2005).

Just recently, the knowledge spillover theory of entrepreneurship (Acs et al. 2004, 2005) was introduced to establish an explicit link between knowledge and entrepreneurship within the spatial context. The knowledge spillover theory of entrepreneurship posits that investments in knowledge by incumbent firms and research organizations such as universities will generate entrepreneurial opportunities because not all of the new knowledge will be pursued and commercialized by the incumbent firms. As Arrow (1962) pointed out, new knowledge is inherently uncertain and asymmetric, so that incumbent firms and other organizations are unable to recognize and act upon all of the knowledge created by their own investments. What one (knowledge) worker perceives to be a potentially valuable idea may not actually be acknowledged as being valuable by the decision-making hierarchy of the firm. The knowledge filter (Acs et al. 2004) refers to the extent that new knowledge remains uncommercialized by the organization creating that knowledge. It is these residual ideas that generate the opportunity for entrepreneurship. By pursuing ideas and knowledge created but left uncommercialized in an incumbent firm or organization, the entrepreneurial venture serves as a conduit of knowledge spillovers. In other words: knowledge spillovers are viewed as a major cause of entrepreneurship.

Recent empirical studies have found that new-firm start-ups are systematically greater in regions rich in knowledge than in regions poor in knowledge (Audretsch and Keilbach 2007; Audretsch et al. 2006). ${ }^{2}$ These studies implicitly assume that, given a certain investment in knowledge, economic agents will automatically identify and act upon entrepreneurial opportunities. That is, the capabilities of economic agents

\footnotetext{
2 Moreover, Audretsch and Dohse (2007) are able to show that being located in an agglomeration rich in knowledge resources is more conducive to firm growth than being located in a region that is less endowed with knowledge resources.
} 
within the region to actually access and absorb the knowledge and ultimately utilize it to generate entrepreneurial activity are implicitly assumed to be invariant with respect to geographic space.

However, such an assumption violates one of the most significant insights by Jane Jacobs (1969), later echoed by Porter (1990), Glaeser et al. (1992), Feldman and Audretsch (1999), that regions with more diversity will facilitate the spillover of knowledge, which in turn should trigger more entrepreneurial activity. According to Jacobs, it is differences among people that foster looking at a given information set differently, thereby resulting in different appraisal of any new idea. After all, if all economic agents were perfectly homogeneous, a total consensus would reign with respect to any new idea, and there would be no reason to start a new firm. As Jacobs emphasized, it is differences across economic agents that lead to divergences in the valuation of new ideas, and it is these divergences in the value of ideas that trigger people to start a new venture. Diverse backgrounds and perspectives embedded in a diverse set of agents may lead one person to decide an idea is potentially valuable while others, including the decision making hierarchy of incumbent organizations, do not. The more different kinds of people evaluate any given idea, the higher will be the probability that one of these persons will arrive at the conclusion that she wants to commercially exploit it.

Thus, while knowledge may be important to generate new ideas, it is the assessment of those new ideas by diverse economic agents characterized by differences in experiences, backgrounds, and capabilities that leads to divergences in the valuation of such ideas which ultimately induce agents to resort to entrepreneurship to appropriate the value of their knowledge endowments. This suggests that for knowledge spillovers to occur, more than investments in new knowledge is required. Rather, economic agents with the capabilities to access, absorb and commercialize that knowledge through the spillover conduit of entrepreneurship are also essential for generating knowledge spillovers. Diversity will enhance such entrepreneurial activity because diverse economic agents will value new ideas differently, leading them to respond to different ideas in a different way. It is this diversity in economic agents that triggers divergences in the evaluation of new ideas that is the basis for knowledge spillover entrepreneurship. Thus, those regions with more diversity would be expected to generate more entrepreneurial activity. By contrast, less diversity, or more homogeneity, would be expected to generate less entrepreneurship. In particular, diversity with respect to backgrounds, experience and interest should generate diversity with respect to evaluations of new ideas, which, as explained above, should trigger more individuals to reach the decision to become an entrepreneur.

Glaeser et al. (1992) and Feldman and Audretsch (1999) provided compelling evidence linking diversity to regional economic growth. However, in both of these influential studies, diversity was measured in terms of economic activity within the region, which reflects firms, but not in terms of the people actually living and working in the region. This misses the essential diversity argument by Jacobs, which is first and foremost about people and not necessarily firms. Thus, a major contribution of this paper is not only to link regional entrepreneurial activity to diversity in terms of firms but also people. So, unlike earlier papers we consider the significance of different dimensions of diversity for firm foundation, namely sectoral diversity and 
cultural diversity. ${ }^{3}$ Sectoral diversity is probably the most common concept. The indicators of sectoral diversity used in this paper are calculated with employment shares of industries documented in the appendix. More important-and from a theoretical point of view more adequate-we apply an indicator that refers directly to the diversity in terms of people. We use information on regional employment by nationality to calculate our measure of cultural diversity (see Sect. 3 for details). Cultural diversity is supposed to capture diversity of economic agents (with respect to their experience, background and capabilities) which is expected to facilitate exploitation of a given regional knowledge base and thus promote entrepreneurial activity.

\subsection{The econometric model}

In order to arrive at robust results regarding the impact of different diversity measures, the regression analysis departs from a model that includes a number of factors that have turned out to be important determinants of the regional firm birth rate in the empirical literature. These control variables include measures of the density of economic activities (such as population density), the disposable income in the region under consideration and in neighbouring regions (spatially lagged exogenous variable), growth of disposable income, growth of disposable income in neighbouring regions, unemployment and an indicator of the firm size structure of the region (share of small firms in total employment).

The econometric model in its basic version has the form:

$$
\mathrm{SU}_{i t}=\alpha_{0}+\sum_{l=1}^{L} \alpha_{l} \mathrm{KNOW}_{l i t}+\sum_{m=1}^{M} \beta_{m} \mathrm{DIV}_{m i t}+\sum_{n=1}^{N} \gamma_{n} \mathrm{CONTROL}_{n i t}+u_{i t}
$$

where $\mathrm{SU}_{i t}$ is the start-up intensity (start-ups per 10.000 inhabitants) in region $i$ and year $t, \mathrm{DIV}_{\text {mit }}$ is diversity measure $m$ in region $i$ and period $t, \mathrm{CONTROL}_{n i t}$ is control variable $n$ in region $i$ and period $t$. Moreover, we include two knowledge variables $\mathrm{KNOW}_{l i t}$, the share of R\&D workers in total employment, and the percentage of highly skilled employees. Spatial lags of the knowledge variables are considered as well since the spatial range of spillover effects might exceed the borders of our observational units. The error term is denoted by $u_{i t}$ and assumed to be identically and independently distributed with mean $\mu_{u}$ and variance $\sigma_{u}^{2}$.

\footnotetext{
3 The reader might ask how sectoral and cultural diversity relate to the notions of localization economies and urbanization economies introduced by Hoover (1937). According to Hoover, localization economies are economies external to the firm and internal to a specific industry, whereas urbanization economies are external to the industry and internal to the city. Thus, a high level of sectoral concentration in a region (reflected by a low value of the sectoral diversity index) may indicate that there exist localization economies. On the other hand, there is no simple correspondence between our diversity measures and urbanization economies. Our concepts are rather specific, either relating to the sectoral distribution (=sectoral diversity) or the ethnic/cultural distribution (=cultural diversity) of a region's employees. The concept of urban diversity which underlies the notion of urbanization economies is, by contrast, much broader as it refers to diversity with respect to virtually any type of characteristic(s) within an urban or geographic unit of observation.
} 
To check the robustness of results emerging from the pooled model given in Eq. (1), we apply additional regression models. Panel data models are used to control for unobserved time-invariant explanatory variables:

$$
\begin{aligned}
\mathrm{SU}_{i t}= & \alpha_{0}+\sum_{l=1}^{L} \alpha_{l} \mathrm{KNOW}_{l i t}+\sum_{m=1}^{M} \beta_{m} \mathrm{DIV}_{m i t}+\sum_{n=1}^{N} \gamma_{n} \text { CONTROL }_{n i t} \\
& +\eta_{i}+\lambda_{t}+v_{i t}
\end{aligned}
$$

where $\eta_{i}$ denotes a region-specific effect, controlling for unobservable regional characteristics that are time-invariant. $\lambda_{t}$ captures unobservable time effects and $v_{i t}$ is a white noise error term. We estimate fixed effects as well as random effects specifications.

Another innovation of the paper is that we consider start-ups at different technology levels as the factors driving start-ups might differ considerably with respect to technology level. The models given by Eqs. (1) and (2) are estimated for different technology levels, i.e. we consider overall start-up intensity, technology oriented start-ups, firm birth in technology oriented services and high tech start-ups as dependent variables. Simply comparing the estimates of the four models will provide first insights into variations regarding determinants of regional firm birth rates at different technology levels. This analysis is complemented by a more detailed investigation of corresponding differences. We pool the data of different firm birth rates, estimate coefficients specific to a particular technology level and perform $F$ tests on equality of the slope estimates in order to check whether the impact of the explanatory variables differs systematically among technology levels. ${ }^{4}$

\section{Data description}

\subsection{Units of observation}

The cross section consists of 97 functional regions, so-called Raumordnungsregionen, which comprise several counties (NUTS 3 level) linked by intense commuting. ${ }^{5}$ Thus, the observational units represent regional labour markets. Since this definition of regions does not account for other forms of economic activity such as consumption, we care for possible spillover effects caused, e.g. by demand linkages and other kinds of spatial interaction via spatial econometric methods, i.e. including spatial lags of explanatory variables.

\footnotetext{
4 We pool the data and estimate the model without constraining the residual variances of different start-up intensities to be the same. Constraining the variances might severely affect the results of the $F$ tests.

5 According to a definition by the German Federal Office for Building and Regional Planning (BBR) Raumordnungsregionen are intended to be comparable regions "that reflect in acceptable approximation the spatial and functional interrelation between core cities and their hinterland" (BBR 2001: 2).
} 
Table 1 Correlations of firm birth rates at different technology levels

\begin{tabular}{lllll}
\hline & Start-Up Rates & & \\
\cline { 2 - 4 } & Total & High tech & $\begin{array}{l}\text { Technology } \\
\text { oriented } \\
\text { services }\end{array}$ & $\begin{array}{l}\text { Not } \\
\text { technology } \\
\text { oriented }\end{array}$ \\
\hline Total $\left(S u \_a l l\right)$ & & & & \\
High tech $\left(S u \_h t\right)$ & 1.00 & & 1.00 & 1.00 \\
Technology oriented services $\left(S u_{-} t o s\right)$ & 0.66 & 0.42 & 0.53 & \\
Not technology oriented $\left(S u \_n t o\right)$ & 0.99 & 0.05 & & \\
\hline
\end{tabular}

Source: ZEW start-up panel, own calculations

\subsection{Dependent variables}

We measure regional entrepreneurship in terms of start-up intensity, i.e. start-ups per 10.000 inhabitants. As the annual variation in birth rates of innovative firms is high we follow the recommendation of the data provider (ZEW Mannheim) and use 4-year averages (1998-2001 and 2002-2005, respectively) of firm birth rates as dependent variables in the regression analyses. ${ }^{6}$ Unlike earlier papers, we do not only consider total start ups but differentiate between firm birth rates at different technology levels. In the remainder of the paper we focus on four different groups of start-ups, namely total start-ups $\left(S u \_a l l\right)$, technology oriented start-ups $\left(S u \_t o\right)$ which make out roughly $10 \%$ of all start-ups, and two particularly interesting and important sub-groups of technology oriented start-ups, i.e. start-ups in technology oriented services $\left(S u \_t o s\right)$ and the small but classy group of high tech start-ups $\left(S u \_h t\right) .{ }^{7}$ A detailed description of the data set and the classification of start-ups according to their technology level can be found in the documentation by Metzger and Heger (2005). ${ }^{8}$

As the majority of start-ups are not technology oriented, the firm birth rate of low tech businesses $(\mathrm{Su}$ ntoto) is highly correlated with the measure for overall firm foundation $\left(S u \_a l l\right)$ which can be seen from Table 1 . We therefore refrain from considering $S u \_n t o$ as a category of its own in the empirical part of the paper.

Moreover, the spatial pattern of firm birth rates at different technological levels is subject to a considerable variation, as indicated by the correlation coefficients in Table 1. The correlation between total firm birth and start-ups in technology oriented services $\left(S u \_t o s\right)$ amounts to 0.66 , whereas the coefficient between the overall rate

\footnotetext{
6 It should be noted that the information on start-ups only relates to headquarters and that new subsidiaries are not contained in the ZEW-data.

7 As Armington and Acs $(2002,34)$ observe, while "... much of the literature on new firm formation in the 1980s was motivated by high levels of unemployment in traditional industrial regions, much of the focus on new firm start-ups today is motivated by high technology start-ups that are thought to be driving the new economy."

8 It should be noted that according to ZEW the start-up rates for some regions tend to be upward biased due to regional differences in the data survey mode. We therefore exclude the corresponding observations (Hamburg, period 1998-2001; Oberfranken, Westpfalz and Rheinpfalz, period 2002-2005 and Braunschweig, both periods) from the database.
} 
of firm foundation and high tech start ups $\left(S u \_h t\right)$ is merely 0.13 . There are also pronounced disparities within the class of technology oriented start-ups as shown by the modest correlation among new high tech firms and technology oriented services (0.42). This suggests that firm birth of different technological categories might be driven by different factors.

The substantial spatial variation of firm birth rates at different technological levels is also illustrated in Figs. 1 and 2. While regions with a total start-up intensity ( $\mathrm{Su}$ _all) in the upper tail of the distribution can be found in the northern and eastern parts of the country as well as in the south and the west, we observe a striking concentration of regions with particularly high start-up intensities in technology oriented industries $\left(S u_{-}\right.$to $)$in the southern parts of the country, i.e. in the states Bavaria, Baden-Württemberg and (the south of) Hesse.

Figures 3 and 4 in appendix show that the spatial distribution of start-ups in technology oriented services $\left(S u \_t o s\right)$ is quite similar to the spatial distribution of technology oriented start-ups in general while the high tech start-up-rate $\left(S u \_h t\right)$ appears to be particularly high in the outmost south-west (Baden-Württemberg).

\subsection{Explanatory variables}

In order to arrive at robust results regarding the impact of different diversity measures the regression analysis departs from a model that includes a number of factors that have turned out to be important determinants of the regional firm birth rate. We deal with potential endogeneity of some influential factors by using predetermined explanatory variables. Thus, as regards the average firm birth rate 1998-2001 (2002-2005) the explanatory variables refer to 1997 (2001) —unless stated otherwise. Several explanatory variables used in the regression model are based on employment data provided by the German Federal Employment Agency. The employment statistic covers all employment subject to social security contributions. ${ }^{9}$ The information refers to workplace location. We use employment data differentiated by nationality, educational level, industry and firm size to generate several diversity measures and control variables that enter into the regression model.

As mentioned before there is a rich and growing literature on regional variation in new firm formation. The first larger wave of papers published in the early 1990s found significant regional variation in firm start-ups, and the explanatory variables that were usually found to be most important were various measures of unemployment, population density, industrial structure, taxes and regional (income) dynamics. These more traditional variables are considered as control variables in our econometric analysis and they are described in Sect. 3.3.1 in more detail. ${ }^{10}$

Recent theoretical developments such as the rise of the endogenous growth theory, the new economic geography and-most recently—-the knowledge spillover theory

\footnotetext{
9 Hence, civil servants and self-employed are not recorded in the employment statistic.

10 We do not consider taxes because business tax rates in Germany are either set at the federal level (corporate income tax) or at the level of municipalities, and there are no data available that aggregate taxes levied at the level of municipalities to the level of counties or planning regions.
} 


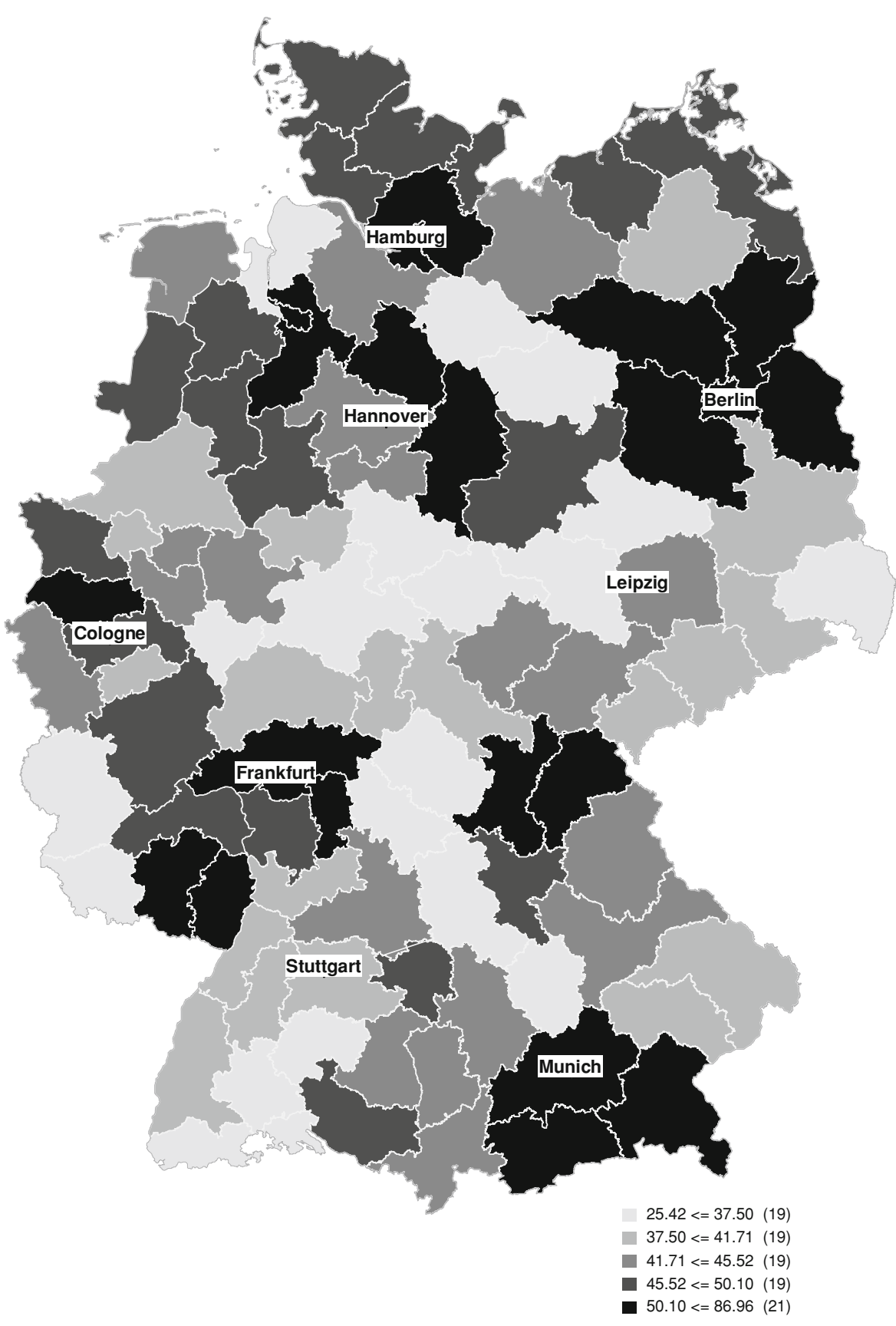

Fig. 1 Regional distribution of start-up rates -all start-ups 1998-2001 (data source: ZEW start-up panel)

of entrepreneurship led to a shift in the research focus to knowledge variables such as R\&D and human capital. These knowledge variables form the second group of explanatory variables in our empirical analysis, and they are described in Sect. 3.3.2. 


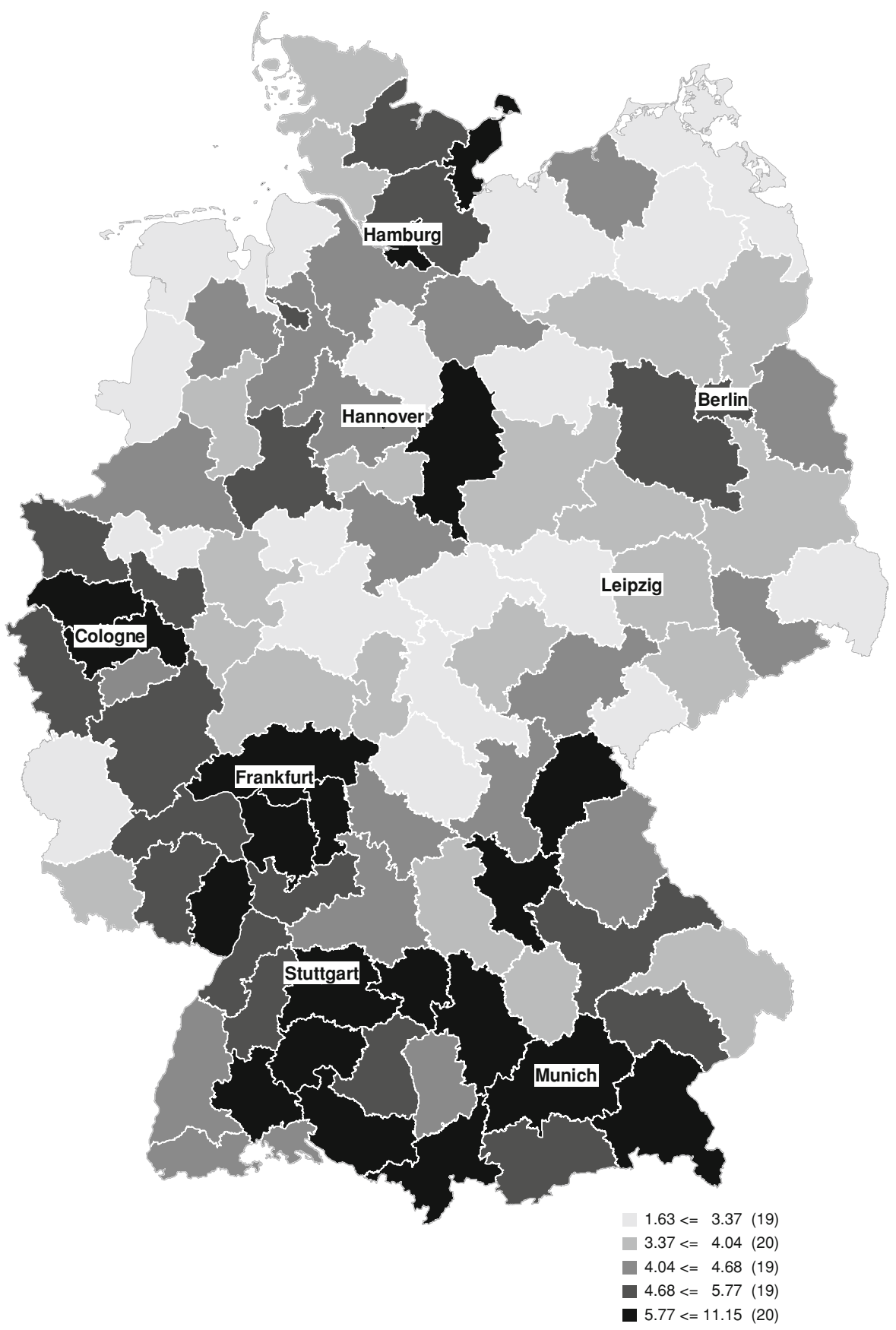

Fig. 2 Regional distribution of start-up rates - technology oriented start-ups 1998-2001 (data source: ZEW start-up panel) 
Finally, as argued in Sect. 2, the spillover of new knowledge and the realization of entrepreneurial opportunities depends for various reasons on the composition of the regional population. Our central hypothesis is that the higher the ethnic (and thus cultural) diversity of the economic agents living and working in a region the higher is the chance that entrepreneurial opportunities are recognized and put into practice. Regional diversity measures are discussed in more detail in Sect. 3.3.3.

\subsubsection{Control variables}

As a first control variable we consider the regional unemployment rate, i.e. the number of unemployed as a percentage of the regional labor force (UR). Conflicting hypotheses are discussed in the entrepreneurship literature regarding the impact of unemployment. Some authors argue that in case of high unemployment the propensity of people to start their own business might increase because of lacking alternative job opportunities. Based on this argument, one might expect that regions characterized by high unemployment rates realize high rates of new firm foundation. However, high unemployment can also indicate economic decline and low consumer demand. In this case a high rate of unemployment is likely to exert a dampening effect on entrepreneurship. The empirical evidence concerning the impact of unemployment on start-ups is rather contradictory and unclear. While Wagner and Sternberg (2004) find that being unemployed increases the propensity to start one's own firm, other studies find no significant or even a significantly negative impact of the unemployment rate (Reynolds et al. 1994; Sutaria and Hicks 2004).

The density of economic activity in a region is typically found to have a positive impact on start-ups (Reynolds et al. 1994; Armington and Acs 2002; Fritsch and Falck 2007). The density measure PD (population density) used in the context of this paper is defined as inhabitants per square kilometer in the German planning regions. In contrast to the knowledge variables discussed in Sect. 3.3.2 the variable PD is included in order to capture the impact of agglomeration economies not directly related to knowledge.

The share of employment in small businesses has been found to be an important start-up determinant in previous studies (Reynolds et al. 1994; Armington and Acs 2002; Sorensen and Audia 2000). A high percentage of small enterprises is generally held to be positive as it may be viewed as a proxy for the entrepreneurial climate and/or entrepreneurial tradition of the region (reflecting the start-up activity of previous periods). A slightly different argument is that working in a small firm fosters the emergence of an entrepreneurial attitude, because smaller businesses have a less extensive internal division of labor such that employees are more likely to get access to knowledge and attain capabilities necessary to run a firm (Beesley and Hamilton 1984; Sorensen and Audia 2000; Fritsch and Falck 2007). ${ }^{11}$ We capture impacts of

\footnotetext{
11 Fritsch and Falck (2007) offer another interesting interpretation of this phenomenon. They argue that the employment share of small firms may be viewed as a proxy for an industry's minimum efficient business size. "The smaller an industry's minimum efficient business size, the fewer the resources that are needed to enter the market successfully, which makes it more likely that new businesses will emerge in that industry" (Fritsch and Falck 2007: 159).
} 
the firm size structure by a variable $S E$, measuring the share of small firms (less than 20 employees) in total employment.

To capture effects linked to the size of the local market and the dynamics of the economic development of the region we include the disposable income of the regions $(I N C)$ and the growth rate of disposable income (INC_G). Information on regional disposable income is available from the national accounts. Spillover effects resulting from a market size that does not correspond with our functional regions is taken into account by spatial lags of explanatory variables. The regression model is extended by spatial lags of disposable income $\left(W_{-} I N C\right)$ and of the growth of disposable income $\left(W_{-} I N C \_G\right)$. Therefore, we investigate whether purchasing power in neighbouring regions has a significant impact on the firm birth rate.

Modelling spillover effects requires some information on the structure of spatial interaction summarized by a spatial weight matrix. We apply two alternative specifications of weight matrices. The first specification involves a binary matrix such that the weights $w_{i j}=1$ if the regions $i$ and $j$ share a border and $w_{i j}=0$ otherwise. Secondly, a weighting scheme based on distance between regions' capitals is considered. We fix a cut-off point of $100 \mathrm{~km}$, i.e. $w_{i j}=0$ if the distance between $i$ and $j$ exceeds this threshold. The weights within the maximum range are calculated as the inverse of distance. All weight matrices are row standardized.

\subsubsection{Knowledge variables}

Creation, diffusion and application of new knowledge are viewed as key drivers of growth in modern economic theories, and knowledge is also a key factor in explaining entrepreneurship. The knowledge spillover theory of entrepreneurship claims that entrepreneurial opportunities emerge as an external effect of R\&D activities pursued by incumbent firms. These R\&D activities create knowledge spillovers which can be exploited by would-be-entrepreneurs. To capture the impact of R\&D and the spillovers it creates we include the share of $\mathrm{R} \& \mathrm{D}$ workers in total employment $(R D)$ as a central explanatory variable in our model. ${ }^{12}$

Moreover, there is rich empirical evidence of a positive relationship between educational attainment and the propensity to start a business (see for instance Bates 1990). We therefore consider the share of highly qualified employees ${ }^{13}$ in total employment $(H Q)$ as a second knowledge variable in our regressions. To allow for knowledge spillovers that exceed the borders of our functional regions we also consider spatial lags of the knowledge variables $\left(W_{-} R D\right.$ and $W_{-} H Q$ ). Again, a binary spatial weight matrix and a distance based weighting scheme are applied alternatively.

It should be emphasized that these explanatory variables do not directly measure knowledge spillovers but, rather, investments in new knowledge. The extent to which

\footnotetext{
12 R\&D employment is defined on the basis of occupations. We consider engineers, chemists, physicists, mathematicians, technicians, other specialised technical staff and natural scientists as R\&D employees.

13 Regionally disaggregated data on highly qualified employees are available from the German Federal Office for Building and Regional Planning (BBR). Highly qualified employees are-according to the definition used by the BBR-employees who hold a university degree, a degree by a technical college (Fachhochschule) or who have graduated from a higher vocational school (Höhere Fachschule).
} 
such knowledge spills over is reflected by the impact of these knowledge variables on the dependent variable, new firm start-ups.

\subsubsection{Diversity measures}

In most empirical studies regional diversity is measured in terms of sectoral diversity. ${ }^{14}$ However, as argued in Sect. 2, for knowledge spillovers to occur and entrepreneurial opportunities to be perceived and put into practice what really matters is the diversity of people rather than the diversity of aggregates such as firms or sectors. For it is the diversity at the level of individuals (i.e. the level of potential entrepreneurs) that increases a region's absorptive capacity for new ideas and facilitates the matching of entrepreneurial opportunities and people able to perceive and realize them. To test this hypothesis we use measures of sectoral diversity (which is still the dominating concept in the literature) alongside with measures of cultural diversity which we argue is the more important concept with respect to the absorption of knowledge spillovers and the exploitation of uncommercialized ideas.

\section{Cultural diversity}

Cultural diversity is sometimes measured by the so-called index of fractionalization ${ }^{15}$ which is identical with the inverse Herfindahl index of ethnic concentration. It may be written as:

$$
\operatorname{FRACT}_{i}=1-\sum_{m=1}^{M_{i}} s_{i m}^{2}
$$

where $s_{i m}$ is region $i$ 's population (or labour force) share belonging to nationality $m$ and $M_{i}$ is the number of different nationalities actually present in region $i$.

This simple index has, however, a very unpleasant characteristic. As the Herfindahl index weights the highest share (in our case the share of Germans in the regional labour force) disproportionately high, the index is largely determined by the share of the dominant population group, i.e. the natives. This means that in the present case the unweighted Herfindahl measure in essence only reflects the share of Germans (foreigners, respectively) and does not account for the distribution of different nationalities within the foreign population.

A more adequate way of measuring cultural diversity is therefore the use of an entropy index. ${ }^{16}$ The simplest and most popular member of the family of entropy indices is the Theil index. For a given region $i$ the Theil index of cultural diversity is defined as the summation of the products of the shares and log shares of each ethnic group in the region's total labor force, i.e.:

\footnotetext{
14 The most prominent studies in this context are Glaeser et al. (1992) and Feldman and Audretsch (1999).

15 The index may be interpreted as the probability that two randomly selected individuals in a community belong to the same group (Ottaviano and Peri 2006).

16 See Shorrocks (1980) and Cowell (2005) for a general discussion and Aiginger and Davis (2004) or Brülhart and Träger (2005) for economic applications of entropy measures.
} 


$$
\operatorname{DIV} \__{i}=-\sum_{m=1}^{M_{i}} s_{i m} \cdot \ln \left(s_{i m}\right)
$$

Note that, if the region has equal sized shares of all population groups $\left(s_{i m}=1 / M_{i}\right)$ then the entropy index reaches its maximum value $\ln \left(M_{i}\right)$ which is, of course, rising with $M_{i}$, the number of different nationalities that are actually present in the region. ${ }^{17}$ If the region is completely specialized (in the sense that the labour force consists of just one ethnic group) the index takes the value $\ln (1)=0$. More generally, the index increases the more evenly a region's population is spread over the $M$ ethnic groups. This implies that the marginal contribution of an additional individual to regional cultural diversity is - ceteris paribus - the higher the smaller the ethnic group to which that individual belongs. An increase in the share of foreign workers-which is equivalent to a decrease of the share of Germans, who are the largest group in all regions - will thus lead to an increase of the index. In a nutshell, the Theil index is an adequate measure of cultural diversity as it reflects the share and the variety ${ }^{18}$ of the foreign population in the region considered. ${ }^{19}$

An alternative way to overcome the conceptual problems of the simple inverse Herfindahl index in measuring cultural diversity is to drop $s_{i 1}$, the share of domestic workers, in the inverse Herfindahl index — which could then be seen as a real diversity measure of the region's foreign labour force-and to multiply this with the share of foreign workers $f w_{i}$ :

$$
\operatorname{DIV}_{-} C_{i}=f w_{i} \cdot\left(1-\sum_{m=2}^{M_{i}} s_{i m}^{2}\right)
$$

This weighted and modified Herfindahl index given in Eq. (5) is another acceptable measure of cultural diversity, although it is less elegant and comfortable than the Theil index. In our econometric analysis we use the Theil index as default and the modified Herfindahl as alternative in order to check the robustness of our results.

\section{Sectoral diversity}

In measuring sectoral diversity the unadapted (inverse) Herfindahl index is less problematic than in measuring cultural diversity because the structure of the data is quite different. ${ }^{20}$ Therefore, it does not matter too much if we use the unadapted Herfindahl

\footnotetext{
17 Note that a total of $M=213$ nationalities are considered in our analysis (with $M_{i} \leq M, i=1, \ldots, 97$ ). Thus, the maximum value of cultural diversity that could theoretically be reached is $\ln (213)=5,36$.

18 Note that both elements are important: A high share of foreigners in itself does not necessarily imply a high cultural diversity if all foreigners belong to the same ethnic (and thus cultural) group. Accordingly, a high diversity of ethnic groups in a region is not sufficient for a high level of cultural diversity if the overall share of foreigners in the region is small.

19 "Variety" - as we understand it—has two dimensions: the "richness" of the foreign labor force (i.e. the number of different nationalities actually present in the region) and the distribution of these different nationalities within the foreign labor force. The Theil index accounts for both.

${ }^{20}$ There is no single sector that dominates the industrial structure of all regions and thus the value of the Herfindahl index.
} 
or the Theil index to measure sectoral diversity. In accordance with the analysis of cultural diversity we will use the Theil index as default and the inverse Herfindahl as control (robustness check) in the econometric part of the paper. The employment shares of 28 industries listed in the appendix were used to calculate the indicators of sectoral diversity.

\section{Empirical analysis}

\subsection{Results of the basic model}

\subsubsection{Knowledge variables}

The results of the basic model as reflected in Eq. (1) are given in Table 2. As can be seen from Table 2, the share of $\mathrm{R} \& \mathrm{D}$ employees (variable $R D$ ) has a significantly positive impact on new firm formation, regardless of the technological level of the start-ups. This is in line with our theoretical expectations that R\&D activities generate entrepreneurial opportunities, as not all of the new knowledge created by R\&D can be recognized and commercialised by those (incumbents) who finance the R\&D. Our findings correspond with evidence provided by Audretsch and Keilbach (2007) as well as Audretsch et al. (2006), indicating that the number of start-ups tends to increase with the regional stock of knowledge. Moreover, one may argue that R\&D employees dispose of a very specific human capital such that people belonging to this group have a particularly high propensity to found new enterprises. Human capital, reflected by $H Q$, the share of highly qualified employees, has a statistically significant positive impact on technology oriented start-up activities in general as well as on start-ups in technology oriented services. ${ }^{21,22}$

The impact of knowledge resources in neighbouring regions is, however, in most cases rather weak. ${ }^{23}$ The estimates suggest that human capital in neighbouring regions ( $W \_H Q$ ) has a weakly significant positive impact on entrepreneurial activity in technology oriented services and no significant impact in all other cases. The weighted share of $\mathrm{R} \& \mathrm{D}$ employees in neighbouring regions $\left(W_{-} R D\right)$ has a significantly negative impact on total start-ups but no significant effect on technology oriented start-ups. A possible explanation for the negative sign of $W_{-} R D$ is that regions with a high level of

\footnotetext{
21 Although the correlation between RD (R\&D employees) and HQ (employees with higher levels of educational attainment) is rather modest (see Table 8 in the appendix) one cannot exclude with certainty that multicollinearity affects the regression results. To check the robustness of our findings with respect to possible multicollinearity we dropped the HQ variable (and, of course, also the spatial lag of HQ) and re-estimated the model in its 12 different versions (four different kinds of start-ups times three different specifications, i.e. pooled OLS, fixed effects and random effects). The omission of HQ and W_HQ resulted in a lower $R^{2}$ and changed some parameter values. The impact of the key diversity and knowledge variables is, however, by and large unchanged by the omission of HQ. We therefore conclude that multicollinearity is negligible as regards our main findings.

22 The results of these robustness checks are available from the authors upon request.

23 This may be due to the fact that our sample regions are rather large such that most knowledge spillovers are intraregional rather than interregional.
} 


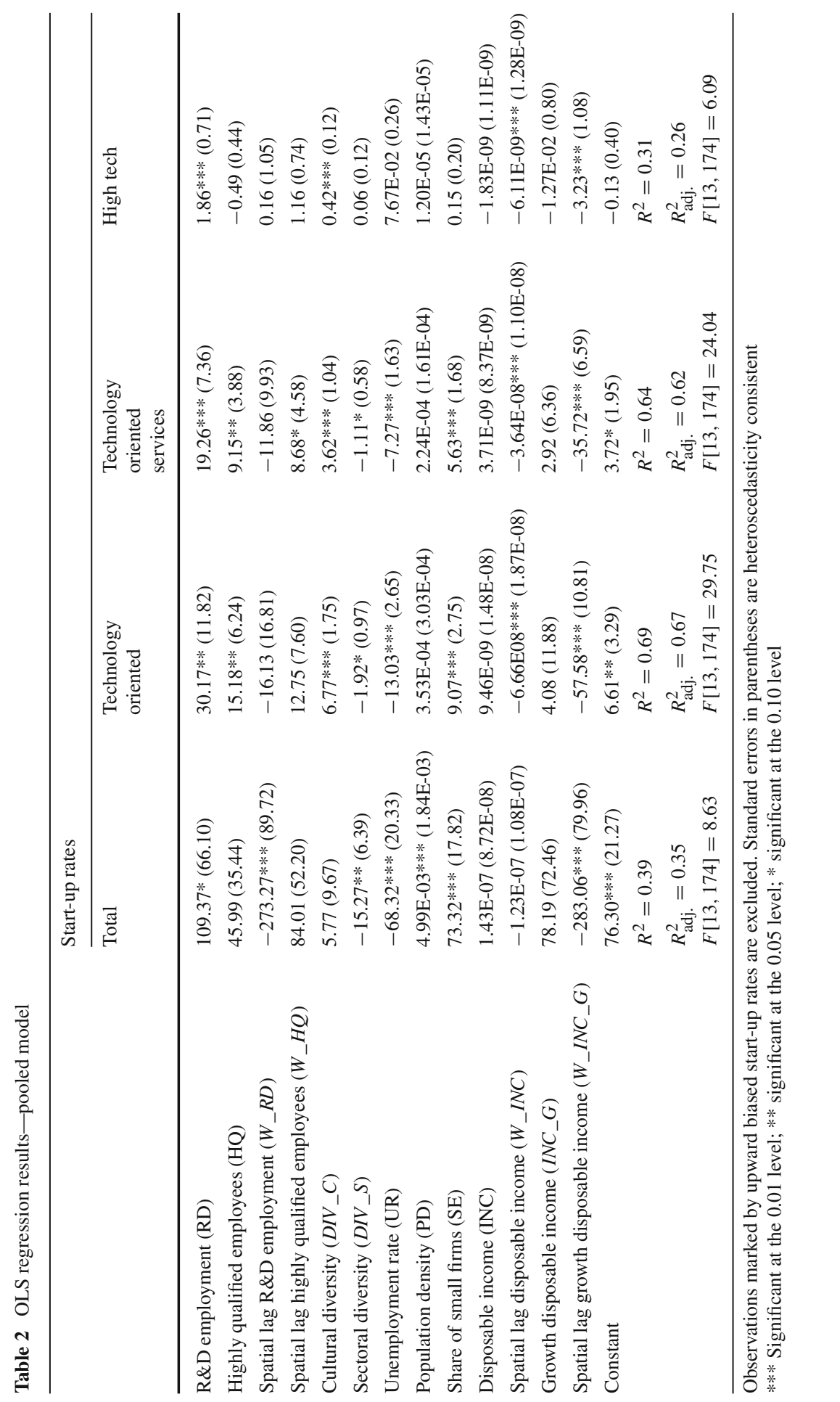


R\&D attract potential entrepreneurs from neighbouring regions, thereby dampening entrepreneurial activity in the home region.

\section{Regional diversity}

Of particular interest with respect to the objective of this paper is the impact of regional diversity on entrepreneurial activity. As can be seen from Table 2, the empirical results for sectoral diversity $\left(D I V \_S\right)$ are somewhat ambiguous. Sectoral diversity tends to exert a negative effect on new firm formation which is significant in the model for total start-ups and weakly significant in the case of technology oriented start-ups in general and technology oriented services, but has no statistically significant impact on high-technology start-ups. This suggests that — at least for start-ups that do not fall into the high tech category - the regional concentration of industries and the localization economies associated herewith appear to be more important than economies resulting from the co-location of a wide variety of industries. This is in line with evidence provided by Capello (2002) who investigates the role of urbanization and localization economies with respect to entrepreneurship. According to her results, it is in particular localization economies that matter for firm productivity.

However, as argued above, the essential diversity argument by Jane Jacobs is first and foremost about people and not about firms or sectors, such that cultural diversity — and not sectoral diversity — is the pivotal variable when it comes to perceive and realize entrepreneurial opportunities. Cultural diversity $\left(D I V \_C\right)$ has a positive sign in all models and is highly significant in the case of technology oriented start-ups in general, technology oriented services and high tech start-ups. ${ }^{24}$ This suggests that the diversity of people is indeed more conducive to entrepreneurship than the diversity of firms and that it matters in particular for technology (and thus knowledge) intensive start-ups. ${ }^{25}$ We may thus conclude that regions characterized by a high level of R\&D and a high degree of cultural diversity form an ideal breeding ground for technology oriented start-ups.

\section{Control variables}

As concerns the control variables, the unemployment rate (UR) has a significantly negative impact on all kind of entrepreneurial activities, except for the high tech case. This corresponds with the findings in Sutaria and Hicks (2004). The dampening effect of high unemployment on regional start-up activities might be explained by the fact that more prosperous regions marked by a favourable labour market situation offer better conditions for start-ups than problem regions. Especially in East Germany the dampening impact of high unemployment might considerably reduce start-up

\footnotetext{
24 In the case of total start-ups DIV_C is positive but not significant at the $10 \%$ level.

25 The results displayed in Table 2 are obtained with diversity measures that are based on the Theil index. However, the identified impact of cultural diversity is rather robust with respect to measurement. We get a positive and significant effect of cultural diversity on firm birth rates for an appropriately modified Herfindahl index as well. The results for sectoral diversity are also robust to measurement. See Sect. 4.2.2 for details.
} 
intensity. However, the regression results also suggest that entrepreneurial activity in East German regions is not generally lower than in the western part of the country. A dummy variable for East German regions is not significant in all regression models. $^{26}$

Another important factor is the firm size structure of the region (variable $S E$ ). In line with previous evidence as, e.g. in Armington and Acs (2002), a high percentage of small enterprises (less than 20 employees) in a region appears to be conducive to start-up activity, except for the case of high tech start-ups. This is not surprising since a high percentage of small enterprises may be seen as a proxy for the entrepreneurial climate and/or entrepreneurial tradition of the region, reflecting the start up activity of previous periods. ${ }^{27}$ The population density (PD) variable has a positive sign for all kinds of start-ups we investigated-which is in line with earlier investigations-but is statistically significant only for total start ups.

The region's disposable income (INC) and the growth rate of disposable income have in most models a positive sign but they are not significant at the $10 \%$ level. By contrast, the weighted disposable income of neighbouring regions ( $\left.W_{-} I N C\right)$ and it's growth rate $\left(W_{-} I N C \_G\right)$ have a clearly negative and mostly significant impact on start-ups. A possible explanation is that regions with a high disposable income might attract entrepreneurs from neighbouring areas, thus reducing the firm birth rate there. Potential founders might prefer to start their business in neighbouring regions if these locations offer a large market, as measured by purchasing power, or a particularly dynamic economy, as measured by the growth rate of disposable income in neighbouring regions. ${ }^{28}$

It is noteworthy that the impact of different determinants on firm birth rates appears to differ considerably with respect to the technology level of the start-ups. These differences across start-ups on various technology levels will be analysed more systematically in Sect. 4.3.

\subsection{Robustness checks}

\subsubsection{Panel estimates}

To check the robustness of the pooled regression results discussed so far we include the estimation of panel data models with fixed effects and random effects, i.e. we control for unobserved time-invariant explanatory variables (see Eq. (2) in Sect. 2). Table 3 reports estimates for the fixed effects model, and Table 4 summarizes the estimates for the random effects specification, together with the results of the Hausman tests comparing the fixed effects and the random effects models. The panel models we estimated are consistent with the pooled OLS model, (in other words, they contain all control

\footnotetext{
26 Additional regression results are available upon request.

27 We have no direct measure for the average firm age in a region, but there is, of course, a correlation between firm age and firm size, such that a high percentage of small firms also points to a high percentage of young firms.

28 It should be noted that the correlation between most explanatory variables is relatively low, such that multicollinearity issues should not cause major problems in the regressions (see Table 8 in the appendix).
} 
Table 3 Results of fixed effects model

\begin{tabular}{|c|c|c|c|c|}
\hline & \multicolumn{4}{|l|}{ Start-up rates } \\
\hline & Total & $\begin{array}{l}\text { Technology } \\
\text { oriented }\end{array}$ & $\begin{array}{l}\text { Technology } \\
\text { oriented } \\
\text { services }\end{array}$ & High tech \\
\hline $\begin{array}{l}\text { R\&D employment } \\
\text { (RD) }\end{array}$ & $98.37 * * *(35.96)$ & $43.23 * * *(8.28)$ & $27.01 * * *(4.84)$ & $3.07 * * *(0.75)$ \\
\hline $\begin{array}{l}\text { Highly qualified } \\
\text { employees (HQ) }\end{array}$ & $4.02(21.60)$ & $2.36(4.37)$ & $1.38(2.73)$ & $-1.53 * *(0.50)$ \\
\hline $\begin{array}{l}\text { Spatial lag R\&D } \\
\text { employment } \\
\left(W_{-} R D\right)\end{array}$ & $-113.71 *(66.98)$ & $-8.33(15.13)$ & $-5.66(8.47)$ & $-0.43(1.14)$ \\
\hline $\begin{array}{l}\text { Spatial lag highly } \\
\text { qualified employees } \\
\left(W_{-} H Q\right)\end{array}$ & $134.03 * *(53.07)$ & $-6.68(8.46)$ & $-1.54(4.62)$ & $-0.53(0.98)$ \\
\hline $\begin{array}{l}\text { Cultural diversity } \\
\qquad\left(D I V_{-} C\right)\end{array}$ & $23.00 * *(10.23)$ & $7.82 * * *(1.59)$ & $4.00 * * *(0.90)$ & $0.52 * * *(0.18)$ \\
\hline \multirow{4}{*}{$\begin{array}{l}\text { Sectoral diversity } \\
\quad\left(D I V \_S\right)\end{array}$} & $-13.48 *(7.85)$ & $-1.64(1.32)$ & $-0.70(0.72)$ & $-0.34 * *(0.14)$ \\
\hline & $R^{2}=0.80$ & $R^{2}=0.89$ & $R^{2}=0.88$ & $R^{2}=0.67$ \\
\hline & $R_{\mathrm{adj} .}^{2}=0.54$ & $R_{\mathrm{adj} .}^{2}=0.73$ & $R_{\mathrm{adj} .}^{2}=0.71$ & $R_{\mathrm{adj} .}^{2}=0.25$ \\
\hline & $F[107,80]=3.05$ & $F[107,80]=5.88$ & $F[107,80]=5.41$ & $F[107,80]=1.58$ \\
\hline
\end{tabular}

Observations marked by upward biased start-up rates are excluded. All models also include time fixed effects. Standard errors in parentheses are heteroscedasticity consistent

*** Significant at the 0.01 level; ** significant at the 0.05 level; * significant at the 0.10 level

variables displayed in Table 2). However, for facility of inspection we only report the results for the most important variables, i.e. the knowledge variables and the diversity measures in Tables 3 and $4 .{ }^{29}$ The Hausman test statistics in Table 4 show that in the cases of technology oriented start-ups in general and of technology oriented services the fixed effects specification is the adequate specification, whereas for total start-ups and high tech start-ups the random effects model is preferred.

Comparing Table 3 (results of fixed effects estimation) with Table 2 (pooled OLS) reveals some differences. In the fixed effects specification, $H Q$ is no longer significant in the models for $S u \_t o$ and $S u \_t o s$ and becomes (negatively) significant in the case of $S u \_h t$. Moreover, we arrive at a significant positive effect of $W \_H Q$ on total start-ups. Thus, once unobserved heterogeneity is taken into account, we detect a favourable effect of human capital in neighbouring regions on entrepreneurial activity. However, the results for the $R \& D$ variable and the spatially lagged $R \& D$ variable do by and large resemble those of the pooled OLS model. Most important, with respect to regional diversity the results appear to be quite robust: Again, sectoral diversity tends to exert a negative impact on new firm foundation, whereas cultural diversity has a positive impact. Interestingly, in the fixed effects specification cultural diversity is not only

\footnotetext{
29 The complete tables including the results for the control variables are available from the authors upon request.
} 
Table 4 GLS regression results-random effects model

\begin{tabular}{|c|c|c|c|c|}
\hline & \multicolumn{4}{|l|}{ Start-up rates } \\
\hline & Total & $\begin{array}{l}\text { Technology } \\
\text { oriented }\end{array}$ & $\begin{array}{l}\text { Technology } \\
\text { oriented } \\
\text { services }\end{array}$ & High tech \\
\hline $\begin{array}{l}\text { R\&D employment } \\
\text { (RD) }\end{array}$ & $121.40 * *(60.35)$ & $32.71 * * *(9.69)$ & $21.17 * * *(5.82)$ & $2.28 * * *(0.67)$ \\
\hline $\begin{array}{l}\text { Highly qualified } \\
\text { employees (HQ) }\end{array}$ & $36.59(34.51)$ & $13.43 * *(5.51)$ & $7.59 * *(3.32)$ & $-0.77 * *(0.39)$ \\
\hline $\begin{array}{l}\text { Spatial lag R\&D } \\
\text { employment } \\
\left(W_{-} R D\right)\end{array}$ & $-236.53 * *(93.73)$ & $-14.09(14.98)$ & $-10.05(9.03)$ & $3.53 \mathrm{E}-03(1.05)$ \\
\hline $\begin{array}{l}\text { Spatial lag highly } \\
\text { qualified employees } \\
\left(W_{-} H Q\right)\end{array}$ & $84.74(55.51)$ & $10.78(8.80)$ & $7.28(5.33)$ & $0.85(0.64)$ \\
\hline $\begin{array}{l}\text { Cultural diversity } \\
\qquad\left(D I V_{-} C\right)\end{array}$ & $5.03(9.38)$ & $6.93 * * *(1.48)$ & $3.74 * * *(0.90)$ & $0.45 * * *(0.11)$ \\
\hline $\begin{array}{l}\text { Sectoral diversity } \\
\quad\left(D I V_{-} S\right)\end{array}$ & $-15.13 * *(7.61)$ & $-1.67(1.19)$ & $-0.90(0.73)$ & $-0.05(-0.09)$ \\
\hline Hausman test ${ }^{\mathrm{a}}$ & $18.34(0.15)$ & $27.29(0.01)$ & $27.68(0.01)$ & $8.28(0.83)$ \\
\hline
\end{tabular}

Regions marked by upward biased start-up rates are excluded. All models also include time fixed effects *** Significant at the 0.01 level; ** significant at the 0.05 level, * significant at the 0.10 level

a Test statistic and probability value in parentheses

significant in the three classes of technology oriented start-ups but also in the model for total start-ups.

Comparison of the OLS estimates of the pooled model (Table 2) and the results of the random effects specification (Table 4) confirms that most findings are robust. We detect almost no changes of sign and only a few changes of significance levels. As in the case of the fixed effects specification, especially the evidence regarding the $\mathrm{R} \& \mathrm{D}$ variables and cultural diversity is highly robust. The corresponding coefficients of the random effects model do very much resemble the estimates of the pooled OLS regression model.

Taken together, our main results are fairly robust with respect to different model specifications. Most important, the prominent role of the R\&D variable and cultural diversity is underscored by the panel estimates.

\subsubsection{Alternative diversity measures}

As a further robustness check we have replaced our original, Theil index-based diversity measures by the alternative, Herfindahl index-based measures discussed in Sect. 3.3.3. Again, the presentation of results in Table 5 focuses on the knowledge and diversity variables. ${ }^{30}$ As can be seen from Table 5 (in comparison with Table 2) the alternative diversity measures only lead to marginal changes regarding the influence of knowledge variables and regional diversity on entrepreneurial

\footnotetext{
30 The complete tables including the results for the control variables are available from the authors upon request.
} 
Table 5 OLS regression results_-pooled model with alternative diversity measures

\begin{tabular}{|c|c|c|c|c|}
\hline & \multicolumn{4}{|l|}{ Start-up rates } \\
\hline & Total & $\begin{array}{l}\text { Technology } \\
\text { oriented }\end{array}$ & $\begin{array}{l}\text { Technology } \\
\text { oriented } \\
\text { services }\end{array}$ & High tech \\
\hline $\begin{array}{l}\text { R\&D employment } \\
\quad(\mathrm{RD})\end{array}$ & $108.13 *(64.83)$ & $34.39 * * *(12.15)$ & $21.37 * * *(7.54)$ & $2.73 * * *(0.75)$ \\
\hline $\begin{array}{l}\text { Highly qualified } \\
\text { employees (HQ) }\end{array}$ & $47.26(36.68)$ & $13.20 * *(6.40)$ & $8.13 * *(4.00)$ & $-0.40(0.44)$ \\
\hline $\begin{array}{l}\text { Spatial lag R\&D } \\
\text { employment } \\
\left(W_{-} R D\right)\end{array}$ & $-277.87 * * *(86.26)$ & $-6.48(15.04)$ & $-6.81(8.98)$ & $2.38 * *(1.07)$ \\
\hline $\begin{array}{l}\text { Spatial lag highly } \\
\text { qualified employees } \\
\left(W_{-} H Q\right)\end{array}$ & $86.07(53.11)$ & $10.99(7.42)$ & $7.87 *(4.51)$ & $0.34(0.71)$ \\
\hline $\begin{array}{l}\text { Cultural diversity } \\
\text { alternative measure }\end{array}$ & $72.38(96.83)$ & $57.48 * * *(15.81)$ & $31.09 * * *(9.66)$ & $0.86^{* *}(1.08)$ \\
\hline \multirow{4}{*}{$\begin{array}{l}\text { Sectoral diversity } \\
\text { alternative measure }\end{array}$} & $-128.52 * *(60.87)$ & $-13.94(9.65)$ & $-8.84(5.53)$ & $-0.18(1.27)$ \\
\hline & $R^{2}=0.39$ & $R^{2}=0.68$ & $R^{2}=0.64$ & $R^{2}=0.27$ \\
\hline & $R_{\mathrm{adj} .}^{2}=0.35$ & $R_{\mathrm{adj} .}^{2}=0.66$ & $R_{\mathrm{adj} .}^{2}=0.61$ & $R_{\mathrm{adj} .}^{2}=0.22$ \\
\hline & $F[13,174]=8.62$ & $F[13,174]=28.48$ & $F[13,174]=23.34$ & $F[13,174]=4.94$ \\
\hline
\end{tabular}

Observations marked by upward biased start-up rates are excluded. Standard errors in parentheses are heteroscedasticity consistent

*** Significant at the 0.01 level; ** significant at the 0.05 level; * significant at the 0.10 level

activity. ${ }^{31}$ As concerns the impact of the diversity measures, the coefficients do, of course, deviate from those in Table 2, as the Herfindahl index-based measures have a range from 0 to 1 that differs from the range of the Theil index based-measures, varying from 0 to $\ln (M){ }^{32}$ The important thing is, however, that cultural diversity still has a positive effect on start-ups while sectoral diversity still tends to exert a negative impact.

While the significance of cultural diversity is virtually unchanged when using the alternative measure, sectoral diversity is only significant in the case of total start-ups. ${ }^{33}$ Again, these findings emphasize the importance of distinguishing between different types of diversity. Cultural diversity is found to have a positive impact on entrepreneurship, whereas the impact of sectoral diversity on entrepreneurship tends to be ambiguous or negative.

\footnotetext{
31 We observe only minor changes of significance levels. Worth mentioning is only the significant impact of neighbouring regions' $\mathrm{R} \& \mathrm{D}\left(W_{-} R D\right)$ in the case of high tech start-ups (which was not significant before). 32 Remember that $M$ is the number of nationalities in the index of cultural diversity and the number of sectors in the index of sectoral diversity.

33 In contrast, sectoral diversity also exerted a weakly significant impact on technology oriented start-ups and technology oriented services in the original model.
} 
Table 6 OLS regression results-alternative spatial weights matrix

\begin{tabular}{|c|c|c|c|c|}
\hline & \multicolumn{4}{|l|}{ Start-up rates } \\
\hline & Total & $\begin{array}{l}\text { Technology } \\
\text { oriented }\end{array}$ & $\begin{array}{l}\text { Technology } \\
\text { oriented } \\
\text { services }\end{array}$ & High tech \\
\hline $\begin{array}{l}\text { R\&D employment } \\
\text { (RD) }\end{array}$ & $111.18 *(62.98)$ & $29.68 * *(11.56)$ & $19.36 * * *(7.17)$ & $1.69 * *(0.72)$ \\
\hline $\begin{array}{l}\text { Highly qualified } \\
\text { employees (HQ) }\end{array}$ & $50.56(36.19)$ & $16.86 * * *(6.22)$ & $10.30 * * *(3.87)$ & $-0.45(0.42)$ \\
\hline $\begin{array}{l}\text { Spatial lag R\&D } \\
\text { employment } \\
\text { (W_RD) (distance } \\
\text { weights) }\end{array}$ & $-118.21(94.90)$ & $-5.86(15.49)$ & $-7.99(9.66)$ & $-0.75(1.31)$ \\
\hline $\begin{array}{l}\text { Spatial lag highly } \\
\text { qualified employees } \\
\text { (W_HQ) (distance } \\
\text { weights) }\end{array}$ & $89.24(78.97)$ & $12.65(11.84)$ & $7.51(7.32)$ & $2.11 *(1.25)$ \\
\hline $\begin{array}{l}\text { Cultural diversity } \\
\qquad\left(D I V \_C\right)\end{array}$ & $4.88(8.03)$ & $6.07 * * *(1.35)$ & $3.21 * * *(0.82)$ & $0.46 * * *(0.12)$ \\
\hline \multirow{4}{*}{$\begin{array}{l}\text { Sectoral diversity } \\
\quad\left(D I V \_S\right)\end{array}$} & $-19.60 * * *(6.66)$ & $-2.17 * *(0.94)$ & $-1.20 * *(0.57)$ & $5.77 \mathrm{E}-02(0.12)$ \\
\hline & $R^{2}=0.37$ & $R^{2}=0.69$ & $R^{2}=0.64$ & $R^{2}=0.32$ \\
\hline & $R_{\mathrm{adj} .}^{2}=0.32$ & $R_{\mathrm{adj} .}^{2}=0.67$ & $R_{\mathrm{adj} .}^{2}=0.61$ & $R_{\mathrm{adj} .}^{2}=0.27$ \\
\hline & $F[13,174]=7.80$ & $F[13,174]=29.51$ & $F[13,174]=23.62$ & $F[13,174]=6.23$ \\
\hline
\end{tabular}

Observations marked by upward biased start-up rates are excluded. Standard errors in parentheses are heteroscedasticity consistent

$* * *$ Significant at the 0.01 level; ** significant at the 0.05 level; * significant at the 0.10 level

\subsubsection{Alternative spatial weights matrices}

Working with alternative spatial weights matrices (a distance-based weighting scheme instead of the standard binary matrix) has little effect on the impact of the diversity and intra-regional knowledge variables as can be seen by a comparison of Table 6 and Table 2. The influence of knowledge in neighbouring regions remains weak although there are some minor changes: $R \& D$ in neighbouring regions has no longer a significant impact on total start-ups, whereas a high percentage of highly qualified workers in neighbouring regions has a weakly significant (positive) impact on high tech start-ups. These are, however, only marginal changes that leave our main findings unaffected.

To sum up, our main results concerning the impact of cultural diversity and knowledge on start-ups at different technology levels appear to be rather robust with respect to alternative specifications regarding diversity measures or spatial weighting matrices.

\subsection{Tests of parameter stability across different technology levels}

A comparison of the different models summarized in the columns of Table 2 reveals that there are significant differences with respect to the factors that turn out to be 
Table $7 \quad F$ test on equality of slope estimates

\begin{tabular}{|c|c|c|c|c|}
\hline & \multicolumn{4}{|l|}{ Reference } \\
\hline & \multicolumn{4}{|l|}{ Start-up rate } \\
\hline & \multicolumn{3}{|c|}{$\begin{array}{l}\text { Not technology } \\
\text { oriented firms }\end{array}$} & \multirow{2}{*}{$\begin{array}{l}\text { Technology } \\
\text { oriented } \\
\text { services } \\
\text { High tech }\end{array}$} \\
\hline & $\begin{array}{l}\text { Technology } \\
\text { oriented }\end{array}$ & $\begin{array}{l}\text { Technology } \\
\text { oriented } \\
\text { services }\end{array}$ & High tech & \\
\hline R\&D employment (RD) & 0.23 & 0.45 & 0.94 & $7.97^{* * *}$ \\
\hline $\begin{array}{l}\text { Highly qualified } \\
\text { employees (HQ) }\end{array}$ & 0.69 & 1.04 & 1.75 & $8.01^{* * *}$ \\
\hline $\begin{array}{l}\text { Spatial lag R\&D } \\
\text { employment }\left(W_{-} R D\right)\end{array}$ & 1.22 & 1.43 & 1.82 & 2.02 \\
\hline $\begin{array}{l}\text { Spatial lag highly } \\
\text { qualified employees } \\
\left(W \_H Q\right)\end{array}$ & $7.11^{* * *}$ & $7.51^{* * *}$ & $8.36^{* * *}$ & 1.70 \\
\hline $\begin{array}{l}\text { Cultural diversity } \\
\left(D I V_{-} C\right)\end{array}$ & 0.76 & 0.26 & 0.02 & $12.6^{* * *}$ \\
\hline $\begin{array}{l}\text { Sectoral diversity } \\
\quad\left(D I V_{-} S\right)\end{array}$ & 2.70 & $3.15^{*}$ & $3.83^{*}$ & 2.69 \\
\hline Unemployment rate (UR) & $4.27^{* *}$ & $5.63^{* *}$ & $7.58^{* * *}$ & $12.3^{* * *}$ \\
\hline Population density (PD) & $10.7^{* * *}$ & $11.6^{* * *}$ & $12.9^{* * *}$ & 2.58 \\
\hline Share of small firms (SE) & $10.8^{* * *}$ & $12.4^{* * *}$ & $15.0^{* * *}$ & $9.78^{* * *}$ \\
\hline Disposable income (INC) & $3.12^{*}$ & $3.44^{*}$ & $3.76^{*}$ & 0.49 \\
\hline $\begin{array}{l}\text { Spatial lag disposable } \\
\text { income }\left(W_{-} I N C\right)\end{array}$ & 0.01 & 0.03 & 0.22 & $7.99^{* * *}$ \\
\hline $\begin{array}{l}\text { Growth disposable income } \\
\quad\left(I N C \_G\right)\end{array}$ & 1.33 & 1.41 & 1.54 & 0.24 \\
\hline $\begin{array}{l}\text { Spatial lag growth } \\
\text { disposable income } \\
\left(W \_I N C \_G\right)\end{array}$ & $4.23^{* *}$ & $5.52^{* *}$ & $7.67^{* * *}$ & $15.2^{* * *}$ \\
\hline All coefficients & $5.93^{* * *}$ & $6.23^{* * *}$ & $7.31^{* * *}$ & $21.5^{* * *}$ \\
\hline
\end{tabular}

The $F$ statistics given in the table have an asymptotic distribution with $(1,348)$ degrees of freedom for the tests of individual coefficients and $(13,348)$ degrees of freedom for the test of the entire model. Observations marked by upward biased start-up rates are excluded

*** Significant at the 0.01 level; ** significant at the 0.05 level; * significant at the 0.10 level

important determinants of entrepreneurial activity at different levels of technology. This is confirmed by the results of $F$ tests for parameter stability across different technology levels (see Table 7). In the columns 2 to 4, the coefficient estimates for start-ups that are not technology oriented are confronted with the results for different technology oriented categories. Significant test statistics indicate that the impact of various influential factors differs between start-ups depending on the technology level.

Distinct differences in the size of effects are detected for a number of control variables, but not for our knowledge indicators - apart from the spatial lag of highly 
qualified employees. With respect to the diversity measures, there is some indication for significant differences between high tech start-ups and low tech firm foundation. However, this evidence is restricted to sectoral diversity.

The findings in column 5 suggest that there are also differences among technology oriented start-ups. If we compare the impact of the explanatory variables on technology oriented services and high tech start ups, significant differences arise for some control variables, the knowledge indicators as well as for cultural diversity.

Taken together, these findings clearly suggest that it is important to differentiate between technology levels when the regional determinants of start-up rates are analysed.

\section{Conclusions and outlook}

In this paper we have combined the knowledge spillover theory of entrepreneurship with the diversity argument from urban economics. Our empirical analysis has shown that the determinants of new firm formation differ significantly with respect to the technology level and that it is therefore necessary to distinguish start-ups at different technological levels. We find evidence for the hypothesis that regions with a high level of R\&D and human capital provide more opportunities for entrepreneurship than other regions, whereas the impact of knowledge variables in neighbouring regions appears to be ambiguous.

Regional diversity has a crucial impact on entrepreneurship. However, the relationship between diversity and entrepreneurship depends crucially upon the exact type of diversity considered. While most previous papers have considered regional diversity to be a homogeneous concept, an important contribution of this paper is to distinguish between different types of diversity. In particular, measures of both cultural and sectoral diversity are included in the analysis. The results provide compelling evidence that, in fact, the impact of diversity on entrepreneurship is highly sensitive to the type of diversity measured. While sectoral diversity tends to exert a negative effect on new firm foundation, cultural diversity has a positive and highly significant impact on technology oriented start-ups in general, technology oriented services and high tech start-ups. This suggests that the diversity of people is indeed more conducive to entrepreneurship than the diversity of firms and that regions characterized by a high level of R\&D and a high degree of cultural diversity form an ideal breeding ground for technology oriented start-ups.

The research presented in this paper may be viewed as a modest first step towards a more comprehensive research program. The issue of cultural diversity and entrepreneurship is of high political relevance in modern societies and deserves more attention. Future research should aim at broadening the evidence on this issue by investigating the relationship for other countries. Cross-country studies might also allow to analyse whether there are systematic differences regarding the impact of cultural diversity between classic immigration countries, such as the US and Canada, and highly developed countries characterised by a much shorter migration tradition (e.g. Italy, Spain). 
Moreover, a more detailed differentiation of foreigners could provide insights into the significance of specific nationalities, professions and ethnic groups in fostering the start-up of new businesses at the regional level.

Acknowledgments We would like to thank participants of the international workshop on "Agglomeration and Growth in Knowledge-based Societies" at the Kiel Institute for helpful comments on an earlier version. We are particularly grateful to Rui Baptista, Eckhardt Bode and two anonymous referees for valuable comments and suggestions.

Open Access This article is distributed under the terms of the Creative Commons Attribution Noncommercial License which permits any noncommercial use, distribution, and reproduction in any medium, provided the original author(s) and source are credited.

\section{Appendix}

\section{Industry classification}

The indicator for sectoral diversity is based on employment data by region and industry. The following classification is applied:

1. Agriculture, hunting and forestry

2. Energy

3. Mining

4. Chemical industry

5. Rubber and plastic products

6. Non-metallic mineral mining

7. Glass and ceramics

8. Basic metals and fabricated metal products

9. Machinery

10. Transport equipment

11. Electrical and optical equipment

12. Manufacturing n.e.c.

13. Wood and wood products

14. Pulp, paper and paper products, publishing and printing

15. Leather and textiles

16. Food, beverages and tobacco

17. Construction

18. Wholesale and retail trade

19. Transport and communication

20. Financial intermediation

21. Hotels and restaurants

22. Health and social work

23. Business services

24. Education

25. Leisure-related services

26. Household-related services

27. Social services

28. Public sector 


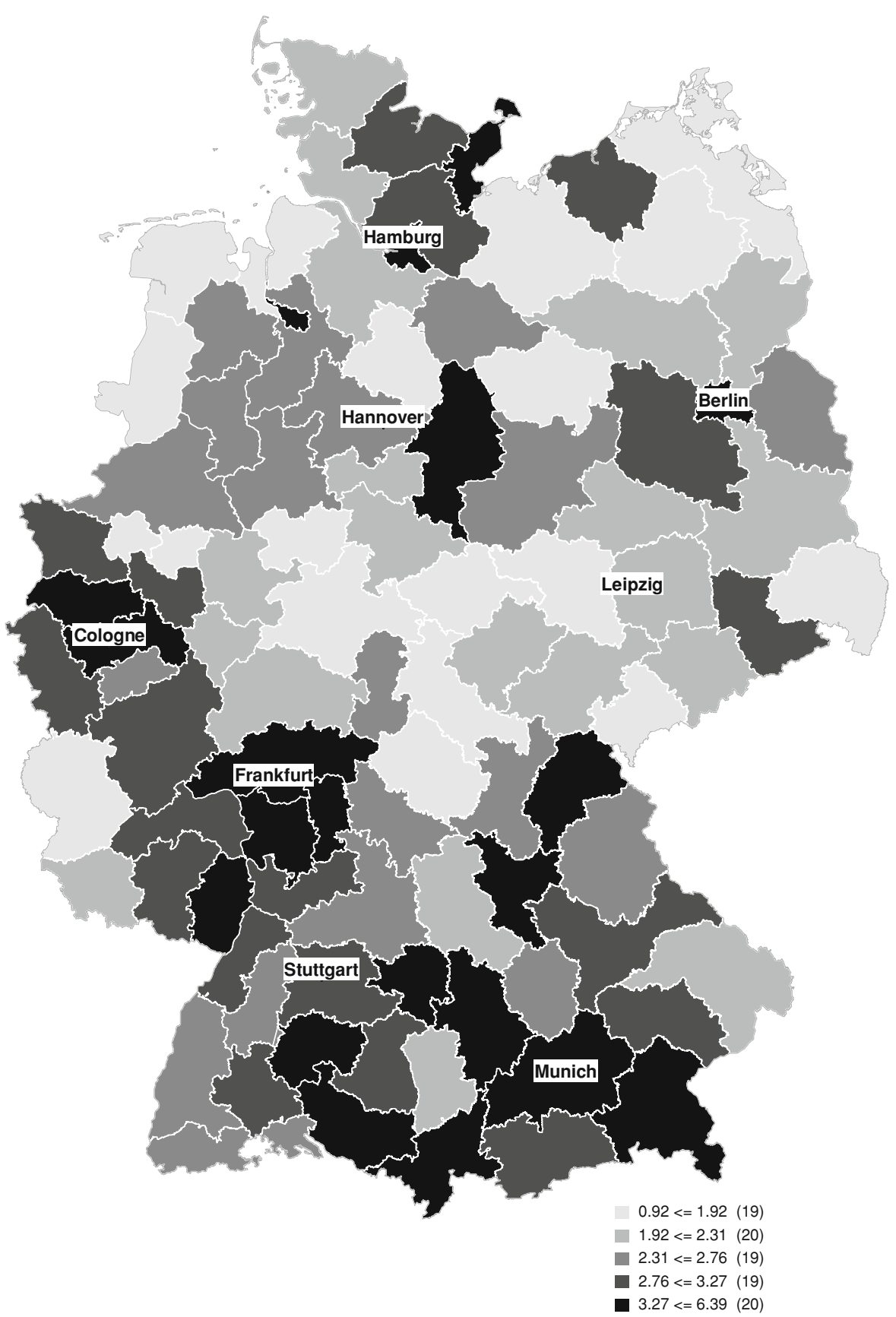

Fig. 3 Regional distribution of start-up rates-technology oriented services 1998-2001 (data source: ZEW start-up panel) 


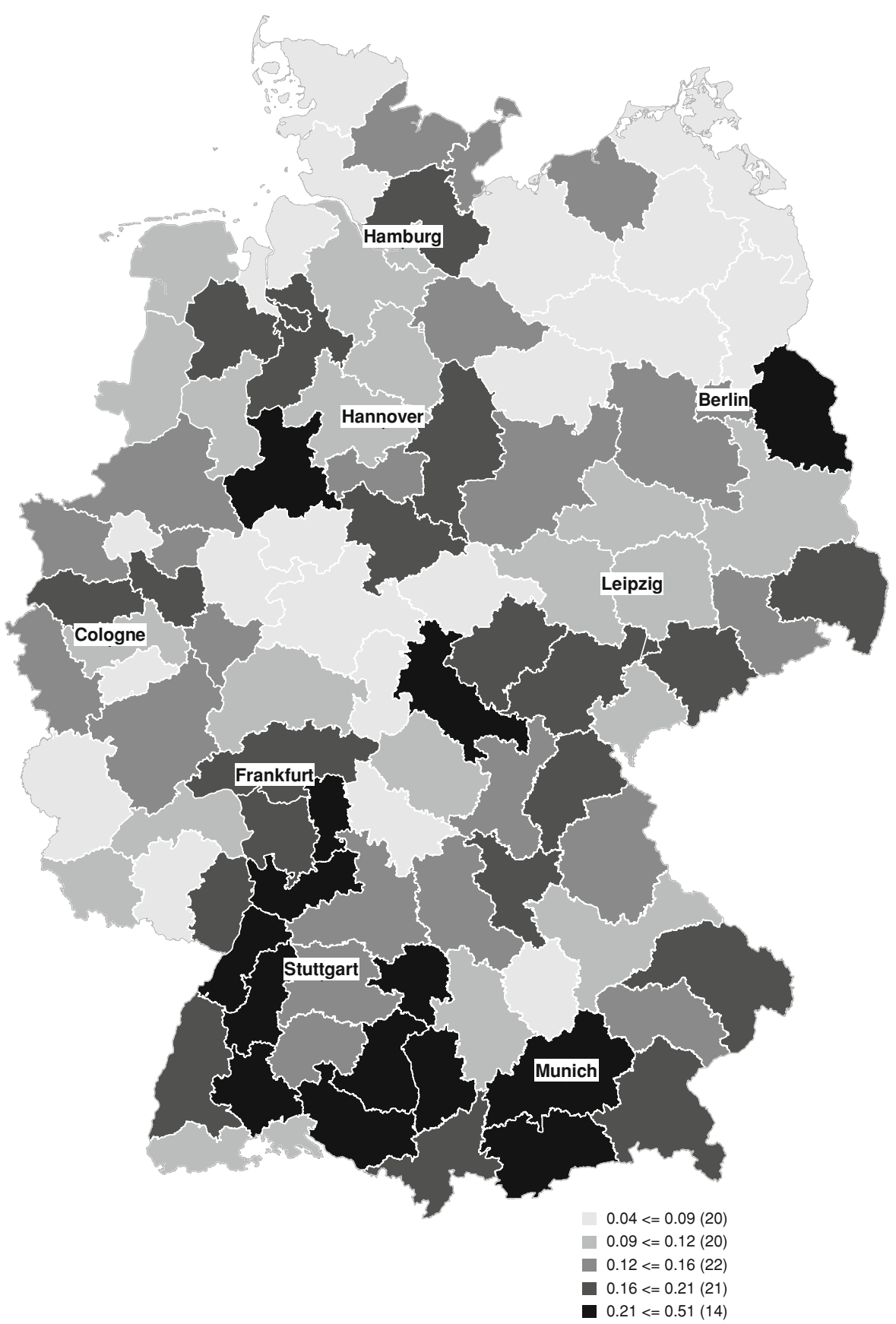

Fig. 4 Regional distribution of start-up rates-high-tech firms 1998-2001 (data source: ZEW start-up panel) 


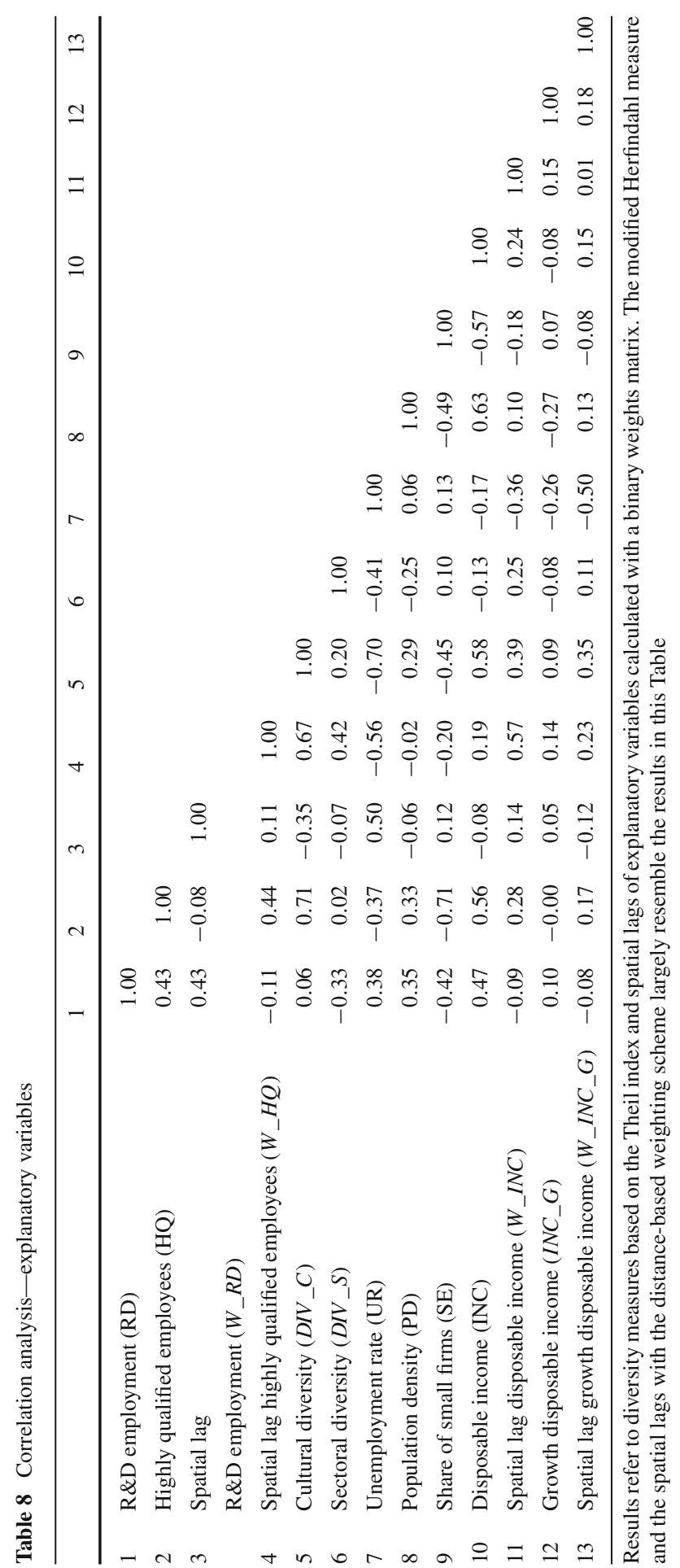


Table 9 Descriptive statistics

\begin{tabular}{|c|c|c|c|c|c|}
\hline & Mean & SD & Minimum & Maximum & $\begin{array}{l}\text { Data } \\
\text { source }\end{array}$ \\
\hline $\begin{array}{l}\text { Start-up rates: Total } \\
\quad\left(S u \_a l l\right)\end{array}$ & 45.0 & 10.1 & 25.4 & 104.9 & 1 \\
\hline $\begin{array}{l}\text { Not technology oriented } \\
(\text { Su_nto) }\end{array}$ & 40.1 & 8.97 & 23.6 & 89.2 & 1 \\
\hline $\begin{array}{l}\text { Technology oriented } \\
\quad\left(S u \_t o\right)\end{array}$ & 4.84 & 1.86 & 1.63 & 15.7 & 1 \\
\hline $\begin{array}{l}\text { Technology oriented } \\
\text { services }\left(S u \_t o s\right)\end{array}$ & 2.81 & 1.04 & 0.92 & 8.81 & 1 \\
\hline High tech $\left(S u \_h t\right)$ & 0.19 & 0.09 & 0.03 & 0.58 & 1 \\
\hline $\mathrm{R} \& \mathrm{D}$ employment (RD) & 0.06 & 0.02 & 0.03 & 0.11 & 3 \\
\hline $\begin{array}{l}\text { Highly qualified } \\
\text { employees (HQ) }\end{array}$ & 0.07 & 0.03 & 0.03 & 0.16 & 2 \\
\hline $\begin{array}{l}\text { Spatial lag R\&D } \\
\text { employment }\left(W \_R D\right)\end{array}$ & 0.06 & 0.01 & 0.05 & 0.09 & 3 \\
\hline $\begin{array}{l}\text { Spatial lag highly } \\
\text { qualified employees } \\
\left(W \_H Q\right)\end{array}$ & 0.07 & 0.02 & 0.04 & 0.12 & 2 \\
\hline $\begin{array}{l}\text { Cultural diversity } \\
\left(D I V \_C\right)\end{array}$ & 0.21 & 0.13 & 0.02 & 0.57 & 3 \\
\hline $\begin{array}{l}\text { Sectoral diversity } \\
\left(D I V \_S\right)\end{array}$ & 2.86 & 0.08 & 2.65 & 3.00 & 3 \\
\hline Unemployment rate (UR) & 0.11 & 0.05 & 0.04 & 0.23 & 2 \\
\hline Population density (PD) & 328.2 & 489.0 & 51.2 & 3867.5 & 2 \\
\hline Share of small firms (SE) & 0.30 & 0.04 & 0.20 & 0.42 & 3 \\
\hline Disposable income (INC) & $13,627,863$ & $10,914,335$ & $2,959,175$ & $57,580,486$ & 4 \\
\hline $\begin{array}{l}\text { Spatial lag disposable } \\
\text { income }\left(W \_I N C\right)\end{array}$ & $14,204,702$ & $5,671,739$ & $4,402,156$ & $32,526,385$ & 4 \\
\hline $\begin{array}{l}\text { Growth disposable income } \\
\qquad\left(I N C \_G\right)\end{array}$ & 0.10 & 0.01 & -0.01 & 0.06 & 4 \\
\hline $\begin{array}{l}\text { Spatial lag growth } \\
\text { disposable income } \\
\left(W \_I N C \_G\right)\end{array}$ & -0.08 & 0.01 & -0.01 & 0.04 & 4 \\
\hline
\end{tabular}

Results refer to diversity measures based on the Theil index and spatial lags of explanatory variables calculated with a binary weights matrix

Data sources: (1) ZEW start-up panel (http://www.zew.de/en/forschung/datenbanken.php3), (2) INKAR data base of the Federal Office for Building and Regional Planning, (3) Employment statistic of the Federal Employment Agency, (4) National accounts of the Federal Statistical Office

\section{References}

Acemoglu D, Aghion P, Zilibotti F (2006) Distance to frontier, selection and economic growth. J Eur Econ Assoc 4(1):37-74. doi:10.1162/jeea.2006.4.1.37

Acs Z, Audretsch D, Braunerhjelm P, Carlsson B (2004) The missing link: the knowledge filter and endogenous growth, Discussion paper. Center for Business and Policy Studies, Stockholm

Acs Z, Audretsch D, Braunerhjelm P, Carlsson B (2005) The knowledge spillover theory of entrepreneurship. CEPR Discussion Paper 5326, London

Aiginger K, Davis S (2004) Industrial specialisation and geographic concentration: two sides of the same coin? Not for the European Union. J Appl Econ 8(2):231-248 
Armington C, Acs ZJ (2002) The determinants of regional variation in new firm formation. Reg Stud 36(1):33-45. doi:10.1080/00343400120099843

Arrow K (1962) Economic welfare and the allocation of resources for invention. In: The rate and direction of inventive activity. Princeton University Press, Princeton, pp 609-626

Audretsch DB, Dohse D (2007) Location: a neglected determinant of firm growth. Rev World Econ 143(1):79-107. doi:10.1007/s10290-007-0099-7

Audretsch DB, Feldmann M (1996) R\&D spillovers and the geography of innovation and production. Am Econ Rev 86:630-640

Audretsch DB, Fritsch M (1994) The geography of firm births in Germany. Reg Stud 28:359-365. doi:10. $1080 / 00343409412331348326$

Audretsch DB, Fritsch M (2002) Growth regimes over time and space. Reg Stud 36:113-124. doi:10.1080/ 00343400220121909

Audretsch DB, Keilbach M (2007) The theory of knowledge spillover entrepreneurship. J Manage Stud 44(7):1242-1254. doi:10.1111/j.1467-6486.2007.00722.x

Audretsch DB, Keilbach M, Lehmann E (2006) Entrepreneurship and economic growth. Oxford University Press, New York

Audretsch DB, Stephan P (1996) Company-scientist locational links: the case of biotechnology. Am Econ Rev 86:641-652

Bates T (1990) Entrepreneur human capital inputs and small business longevity. Rev Econ Stat 72:551-559. doi: $10.2307 / 2109594$

Beesley ME, Hamilton RT (1984) Small firms' seedbed role and the concept of turbulence. J Ind Econ 33:217-231. doi:10.2307/2098510

Blanchflower D, Oswald A (1998) What makes an entrepreneur? J Labor Econ 16(1):26-60. doi:10.1086/ 209881

Brülhart M, Träger R (2005) An account of geographic concentration patterns in Europe. Reg Sci Urban Econ 35:597-624. doi:10.1016/j.regsciurbeco.2004.09.002

BBR (Bundesamt für Bauwesen und Raumordnung) (2001) Aktuelle Daten zur Entwicklung der Städte, Kreise und Gemeinden. Berichte. Band 8: Bonn

Capello R (2002) Entrepreneurship and spatial externalities: theory and measurement. Ann Reg Sci 36:387402. doi:10.1007/s001680200106

Carlton D (1983) The location and employment choices of new firms: an econometric model with discrete and continuous endogenous variables. Rev Econ Stat 54:440-449. doi:10.2307/1924189

Cowell F (2005) Theil inequality indices and decomposition. ECINEQ Working Paper 2005-1, London

Feldman M, Audretsch D (1999) Innovations in cities: science-based diversity, specialization and localized monopoly. Eur Econ Rev 43:409-429. doi:10.1016/S0014-2921(98)00047-6

Fritsch M, Falck O (2007) New business formation by industry over space and time: a multidimensional analysis. Reg Stud 41(2):157-172. doi:10.1080/00343400600928301

Glaeser E, Kallal H, Scheinkman J, Shleifer A (1992) Growth in cities. J Polit Econ 100:1126-1152. doi:10. $1086 / 261856$

Hoover E (1937) Location theory and the shoe and leather industries. Harvard University Press, Cambridge Jacobs J (1969) The economy of cities. Vintage Books, New York

Jaffe A (1989) The real effects of academic research. Am Econ Rev 79:957-970

Jaffe A, Trajtenberg M, Henderson R (1993) Geographic localization of knowledge spillovers as evidenced by patent citations. Q J Econ 63:577-598

Lazear E (2004) Balanced skills and entrepreneurship. Am Econ Rev 94(2):208-211. doi:10.1257/ 0002828041301425

Lee SY, Florida R, Acs Z (2004) Creativity and entrepreneurship: a regional analysis of new firm formation. Reg Stud 38(8):879-891. doi:10.1080/0034340042000280910

Metzger G, Heger D (2005), Die Bereitstellung von Standardauswertungen zum Gründungsgeschehen in Deutschland und Österreich für externe Datennutzer, Version 2005-02, Zentrum für Europäische Wirtschaftsforschung (ZEW), Mannheim

Ottaviano G, Peri G (2006) The economic value of cultural diversity: evidence from US cities. J Econ Geogr 6:9-44. doi:10.1093/jeg/lbi002

Porter M (1990) The comparative advantage of nations. Free Press, New York

Reynolds P, Storey D, Westhead P (1994) Regional variations in new firm formation--special issue. Reg Stud 28:343-456. doi:10.1080/00343409412331348306 
Rocha H, Sternberg R (2005) Entrepreneurship: the role of clusters. theoretical perspectives and empirical evidence for Germany. Small Bus Econ 24:267-292. doi:10.1007/s11187-005-1993-9

Rosenthal S, Strange W (2003) Geography, industrial organizations and agglomeration. Rev Econ Stat 85(2):377-393. doi:10.1162/003465303765299882

Shorrocks A (1980) The class of additively decomposable inequality measures. Econometrica 48(3):613625. doi: $10.2307 / 1913126$

Sorensen O, Audia PG (2000) The social structure of entrepreneurial activity; geographic concentration of footwear production in the United States 1940-1989. Am J Sociol 106:224-262. doi:10.1086/303116

Steil F (1999) Determinanten regionaler Unterschiede in der Gründungsdynamik. Baden-Baden: Nomos

Stuart T, Sorenson O (2003) The geography of opportunity: spatial heterogeneity in founding rates and the performance of biotechnology firms. Res Policy 32:229-253. doi:10.1016/S0048-7333(02)00098-7

Storey D (1991) The birth of new firms-does unemployment matter? A review of the evidence. Small Bus Econ 3:167-178. doi:10.1007/BF00400022

Sutaria V, Hicks D (2004) New firm formation: dynamics and determinants. Ann Reg Sci 38:241-262. doi:10.1007/s00168-004-0194-9

Wagner J, Sternberg R (2004) Start-up activities, individual characteristics, and the regional milieu: lessons for entrepreneurship support policies from German micro data. Ann Reg Sci 38:219-240. doi:10. 1007/s00168-004-0193-x 